\title{
Cadmium metabolism in man
}

\author{
H. WELINDER, S. SKERFVING, AND O. HENRIKSEN ${ }^{2}$ \\ From the Department of Occupational Medicine, University Hospital, S-221 85 Lund, and Facit AB, \\ S-290 70 Svängsta, Sweden
}

ABSTRACT Twenty-one high frequency solderers, who had been exposed to cadmium (Cd) from a solder for periods ranging from 1 month to 18 years (median 8 months; present time-weighted average $30 \mathrm{nmol} / \mathrm{m}^{3}$; particle size below $1 \mu \mathrm{m}$ ) had Cd levels ranging from $<10$ to $440 \mathrm{nmol} / 1$ in blood and from $<0.5$ to $27 \mu \mathrm{mol} / \mathrm{mol}$ creatinine in urine. Individual workers showed considerable variations in blood $\mathrm{Cd}$ levels with time, but less variation in urine levels. There was a statistically significant $(\mathbf{P}<0.001)$ increase of $\mathrm{Cd}$ in urine with increasing exposure time. Four gas solderers, who had been intermittently exposed for 8-20 years (median 17 years) had Cd levels ranging from 45 to $150 \mathrm{nmol} / \mathrm{l}$ and urine levels of from 2 to $20 \mu \mathrm{mol} / \mathrm{mol}$ creatinine. There was no correlation between $\mathrm{Cd}$ levels in blood and urine during exposure. After exposure had ceased there was a considerable decay of blood $\mathrm{Cd}$ in most subjects. The half-time in 11 people ranged from 25 to 146 days (median 41 days). After the decay blood levels reached a steady state. Concentrations in urine did not decrease, or did so only very slowly. There was a significant increase of levels in urine $(\mathbf{P}<0.001)$ with increasing post-decay levels in blood. There was also a significant increase $(0.01<\mathbf{P}<0.05)$ of excretion of $\beta_{2}$-microglobulin in urine (range $1.1-18 \mathrm{mg} / \mathrm{mol}$ creatinine, median $4.7 \mathrm{mg} / \mathrm{mol}$ creatinine) measured 11-15 months after exposure had ceased, with increasing Cd levels in urine. This may indicate an effect on renal tubular function even at kidney $\mathrm{Cd}$ loads corresponding to $\mathrm{Cd}$ levels in urine of the order of as little as $10 \mu \mathrm{mol} / \mathrm{mol}$ creatinine.

Cadmium (Cd) is widely used in industry and its use is increasing. It is also an environmental contaminant which seriously affects the health of the inhabitants of certain areas (Friberg et al., 1974). Exposure may lead to marked accumulation in the kidney, and eventually may cause proximal tubular damage. Toxicological data are scanty in several important aspects, including the metabolism, and also with regard to those critical $\mathrm{Cd}$ exposures and tissue levels which adversely affect the kidney. Such data are crucial for a reliable evaluation of risks connected with exposure, and for establishing guidelines for protective measures for exposed industrial or other

\footnotetext{
'Presented in part at the XVIII International Congress on Occupational Health, Brighton, England, 14-19 September 1975.

${ }^{2}$ Present address: Department of Orthopaedic Surgery, Karlskrona Hospital, S-371 00 Karlskrona, Sweden.

Correspondence to: Staffan Skerfving, MD, and reprint requests to: Hans Welinder, PhD, Department of Occupational Medicine, Univarsity Hospital, S-221 85 Lund, Sweden.

Received for publication 3 November 1976

Accepted for publication 20 January 1977
}

populations. In this study cadmium metabolism and urinary protein excretion were investigated in workers during and after occupational exposure.

\section{Materials and methods}

SUBJECTS STUDIED

The groups studied consisted of 21 high frequency (Hf) solderers and 4 gas solderers (Table 1). The Hf solderers worked in a typewriter factory. For

Table 1 Sex, age, exposure to $C d$, and smoking habits in high frequency $(\mathrm{Hf})$ and gas solderers

\begin{tabular}{lll}
\hline Variables & Hf solderers & Gas solderers \\
\hline Number & 21 & 4 \\
Men & 16 & 4 \\
Women & 5 & 0 \\
$\begin{array}{l}\text { Age, mean and } \\
\text { range (years) }\end{array}$ & $34(19-56)$ & $53(47-59)$ \\
$\begin{array}{l}\text { Exposure time, } \\
\text { median and range }\end{array}$ & $8(1-220)^{*}$ & $210(100-240)$ \\
$\quad$ (months) & 15 & \\
$\begin{array}{l}\text { Smokers } \\
\text { Non-smokers }\end{array}$ & 6 & 1 \\
\hline *Hf solderer 5 had not been exposed to Cd for 15 years.
\end{tabular}


eight hours daily, five days a week they soldered pieces to shafts using a solder containing $18-26 \%$ $\mathrm{Cd}$ and $40 \%$ silver, plus zinc and copper. Each worker had a smoke extractor on his bench. All Hf solderers but one had meals at their benches, usually after a hand wash. After six months' study, a non-Cd solder was substituted for the Cd solder. One of the workers (Hf solderer 5) had not been occupationally exchange to $\mathrm{Cd}$ for 15 years. The median exposure time was eight months.

Three of the gas solderers were employed at the typewriter factory, and one in another metal industry. Their work rooms had ventilation of varying effectiveness. Three gas solderers had meals in the work room, usually after a hand wash. The soldering was performed at irregular intervals. The exposure stopped during the study when the Cd solder was exchanged for a non-Cd solder. The median exposure time was 17 years.

\section{MEDICAL EXAMINATION}

A medical history was obtained with special reference to possible effects of $\mathrm{Cd}$ exposure. Three $\mathrm{Hf}$ solderers had a history of chronic bronchitis. One gas solderer and one Hf solderer had a history of renal calculi, in both cases before onset of $\mathrm{Cd}$ exposure. No other renal diseases were reported. One of the gas solderers had undergone cholecystectomy prior to onset of exposure, and still occasionally felt slight pain. No other liver disease was reported. Two gas solderers had a history of recurrent anaemia. None had hypertension.

A general medical examination was performed. The blood pressures ranged from 115/60-150/90 $\mathrm{mmHg}$, but in one gas solderer was $175 / 100 \mathrm{mmHg}$. Levels of haemoglobin in blood and creatinine in serum were within normal limits, as were the erythrocyte sedimentation rates. In all subjects but one, serum levels of AsT (aspartate aminotransferase, GOT) and AlT (alanine aminotransferase, GPT) were within the normal range. In one subject (Hf solderer 3) markedly increased levels of SAsT (10 $\mu$ kat) and SAIT (16 $\mu \mathrm{kat})$ were unexpectedly found on day 86 , and he was admitted to hospital. Levels of bilirubin and alkaline phosphatase in serum were normal. Au antigen was not detected. SAsT and SAIT returned to normal after 2 months. A mild transient hepatitis was suspected. Semiquantitative determinations of albumin and glucose in urine (Albustix and Clinistix, Ames Company) were negative in all subjects.

CD IN AIR

Representative samples of the air inhaled were collected, on several occasions during the six months before the change to non-Cd solder, on cellulose acetate membrane filters (Millipore; pore diameter $0.8 \mu \mathrm{m}$ ) with individual samplers (MSA pumps; 2-2.5 $1 / \mathrm{min}$ ). Cadmium analysis was by atomic absorption spectroscopy (AAS) after heating the filter in $10 \%$ nitric acid or after acid digestion of the filter, addition of dithizone in buffer solution, and extraction with methyl isobutyl ketone. The overall detection limit was at worst $2.5 \mathrm{nmol} / \mathrm{filter}$. At a sampling volume of $0.5 \mathrm{~m}^{3}$ this corresponds to $5 \mathrm{nmol} / \mathrm{m}^{3}$. Acid digestion of the filter after treatment with nitric acid gave an additional recovery of less than $10 \%$. Analysis of 22 samples collected on 0.22 $\mu \mathrm{m}$ filters in the air stream after it had passed through the $0.8 \mu \mathrm{m}$ filters, indicated a penetration through the latter of average 9\% (range 0-30). Air levels reported below have been corrected for this error.

\section{PARTICLE SIZE}

The particle size distribution was estimated by scanning electron microscopy** (Nucleopore filters, General Electric; pore diameter $0 \cdot 1 \mu \mathrm{m}$ ), at a magnification of $\times 10000$. As large particles may be lost from the filter, their number may be underestimated.

\section{IN BLOOD}

Venous blood was collected in heparinised, acidwashed tubes. Duplicate analyses were performed by AAS after acid digestion of $10 \mathrm{ml}$ blood samples, addition of dithizone in an ammonia-citrate buffer, and extraction of the cadmium dithizonate with methyl isobutyl ketone. The working detection limit was $5-10 \mathrm{nmol} \mathrm{Cd} / \mathrm{l}$ blood. The method error in the interval $0-180 \mathrm{nmol} / \mathrm{l}$, calculated from duplicate analyses, was in the range $5-7 \mathrm{nmol} / \mathrm{l}$.

Ten identical samples which were analysed within a period of eight months by different operators had levels in the range $36-76 \mathrm{nmol} / \mathrm{l}$, an arithmetic mean of $62 \mathrm{nmol} / \mathrm{l}$, and a coefficient of variation of $18 \%$. The accuracy of the method was confirmed by good agreement with independent procedures (AAS and **Analyses performed at AB Analytica, Sollentuna, Sweden.

Table 2 Cadmium levels in blood obtained by atomic absorption spectrophotometry $(A A S)$ and by a neutron activation method $(N A A)$

\begin{tabular}{lcc}
\hline Sample No. & AAS* $($ nmoll $)$ & NAA† $(\mathrm{nmol} / \mathrm{l})$ \\
\hline 1 & 19 & 14 \\
2 & 46 & 53 \\
3 & 49 & 50 \\
4 & 75 & 55 \\
5 & 82 & 98 \\
6 & 88 & 52 \\
7 & 104 & 96 \\
8 & 115 & 129 \\
\hline
\end{tabular}

*Duplicate analyses.

†Single analyses performed at AB Isotopteknik, Stockholm, Sweden. 
Table 3 Cadmium levels in urine obtained by the flame atomic absorpton spectrophotometry (AAS) method used in the present study, and by a flameless AAS method

\begin{tabular}{lcc}
\hline Sample No. & $\begin{array}{l}\text { Flame AAS* } \\
(\text { nmol } /)\end{array}$ & $\begin{array}{l}\text { Flameless AAS } \\
(\text { nmol } / \text { ) }\end{array}$ \\
\hline 1 & 9 & 9 \\
2 & 12 & 12 \\
3 & 29 & 25 \\
4 & 29 & 29 \\
5 & 46 & 51 \\
6 & 69 & 71 \\
7 & 72 & 79 \\
8 & 85 & 84 \\
9 & 120 & 120 \\
10 & 203 & 204 \\
\hline
\end{tabular}

-Duplicate analyses.

†5 analyses in each sample.

neutron activation analysis) in an interlaboratory check (Table 2).

CD IN URINE

PVC bottles which had been rinsed with acid and dithizone in a buffer were used to collect 24-hour urine samples. The analytical method for $\mathrm{Cd}$ was the same as described above for blood, and duplicate analyses were performed. The practical detection limit was about $4 \mathrm{nmol} / 1$ (corresponding to about $0.3 \mu \mathrm{mol} / \mathrm{mol}$ creatinine). Urine analyses were in excellent agreement with results obtained by a flameless AAS method (Table 3).

\section{AAS APPARATUS}

All Cd determinations were carried out on a PerkinElmer Model 403 atomic absorption spectrophotometer using a three-slot burner head and standard operating conditions (Perkin-Elmer Corporation, 1968). A hollow cathode lamp and an electrodeless discharge lamp were used as a light source.

The method control of $\mathrm{Cd}$ in urine was performed on a Perkin-Elmer Model 305 B atomic absorption spectrophotometer with graphite cell and HGA 74 power supply.

CREATININE IN URINE

A spectrophotometric method (Teger-Nilsson, 1961) was used.* Repeated analyses of 10 identical samples gave a coefficient of variation of $2 \%$.

TOTAL PROTEIN IN URINE

Total protein was determined according to Piscator (1962) in morning urine samples obtained 11-15 months after exposure had ended.t

*Analyses performed at Department of Clinical Chemistry, University Hospital, Lund, Sweden.

$\dagger$ Analyses performed by Dr O. Vesterberg, MD, National Board of Occupational Safety and Health, Stockholm, Sweden.
$\beta_{2}$-MICROGLOBULIN IN URINE

Determinations were performed 11-15 months after exposure had ended. The morning urine samples that had been used for total protein determination were used for $\beta_{2}$-microglobulin analysis. In the evening, before the urine was sampled, the worker swallowed $5 \mathrm{~g}$ sodium bicarbonate. The $\mathrm{pH}$ values of the urine samples were subsequently checked to ensure that they exceeded 5.5. A radioimmunoassay (RIA) procedure (Phadebas $\beta_{2}$-micro Test) was used for duplicate analyses (Pharmacia Diagnostics AB, 1975). $\neq$ The detection limit was about $30 \mu \mathrm{g} / 1$ (roughly $2 \mathrm{mg} / \mathrm{mol}$ creatinine). The method error was $13 \mu \mathrm{g} / 1$.

HALF-TIMES OF CD IN BLOOD

The kinetics of $\mathrm{Cd}$ in blood after exposure had ended were calculated by estimation of the constants $A, B$ and $k$ in the model $Y(t)=A+B \cdot e^{-k t}$ using a computerised iterative procedure based on the least squares method.

\section{STA TISTICS}

Linear and multiple regression analysis were used.

¥Analyses performed at Pharmacia Diagnostics AB, Uppsala, Sweden.

Table 4 Cadmium concentration in air at the site of high frequency soldering

\begin{tabular}{ccc}
\hline Cd in air $\left(\mathrm{nmol} / \mathrm{m}^{3}\right)$ & Exposure time* $(h)$ & $\begin{array}{c}\text { Percentage of total } \\
\text { exposure time }\end{array}$ \\
\hline$<10$ & 186.5 & 59.0 \\
$10-19$ & 49.2 & 16.0 \\
$20-29$ & 36.0 & 11.0 \\
$30-39$ & 9.6 & 3.0 \\
$40-49$ & 4.3 & 1.5 \\
$50-99$ & 17.3 & 5.0 \\
$100-199$ & 1.3 & 0.5 \\
$200-299$ & 5.3 & $2 \cdot 0$ \\
$300-399$ & - & - \\
$400-499$ & - & - \\
$500-599$ & - & 2.0 \\
$600-699$ & 7.0 & 100.0 \\
Total & 316.5 &
\end{tabular}

\$85 filters.

Table 5 Particle size distribution in smoke collected at high frequency soldering

\begin{tabular}{ll}
\hline Particle size $(\mu \mathrm{m})$ & Percentage of particles* \\
\hline$<0.1$ & 62.5 \\
$0.1-1.0$ & $37 \cdot 3$ \\
$1 \cdot 1-2 \cdot 0$ & 0.2 \\
$>2.0$ & - \\
Total & 100.0 \\
\hline
\end{tabular}

*500 particles. 

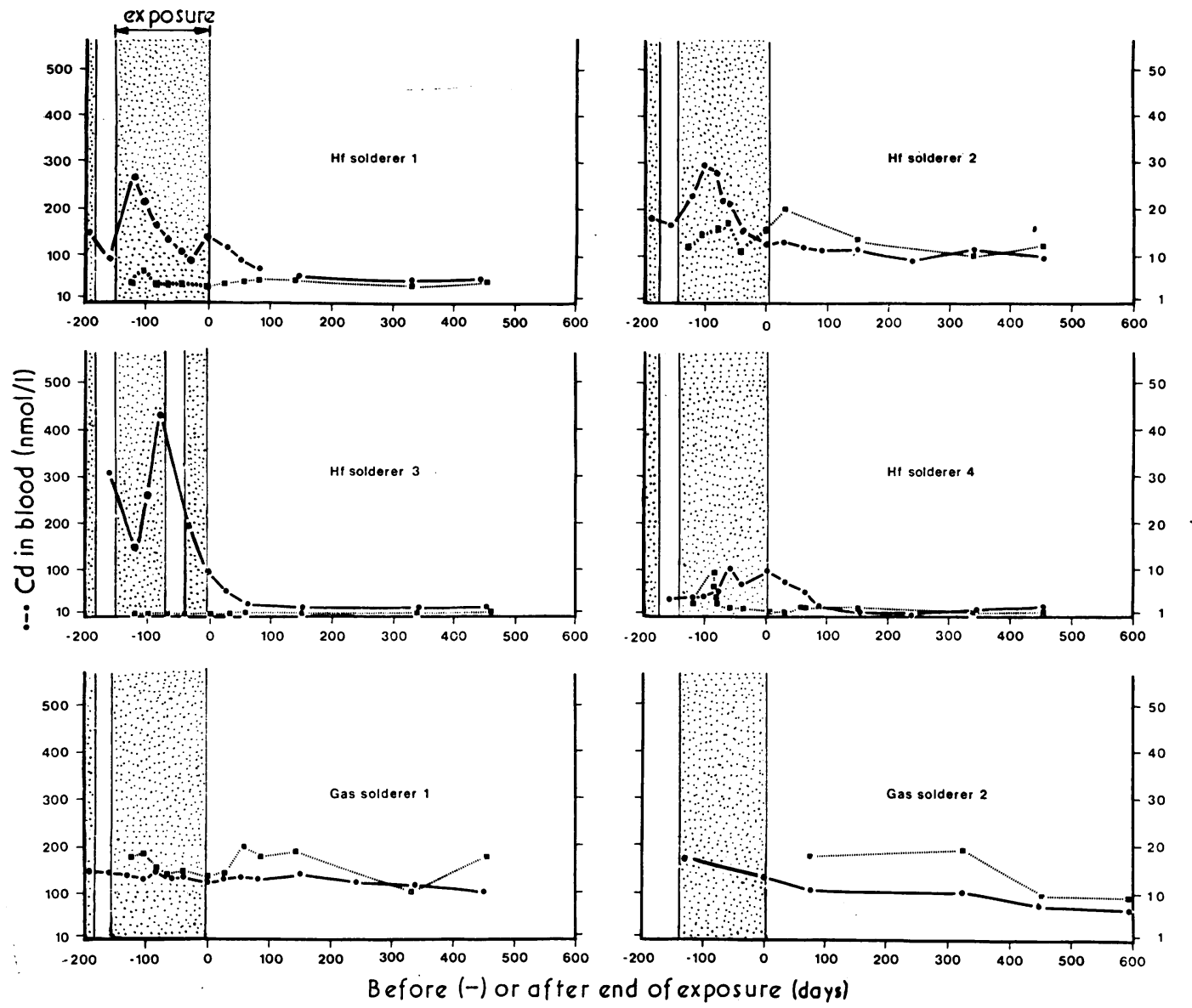

Fig. 1 Levels of cadmium in blood (dots, full lines) and urine (squares, broken lines) in 4 high frequency (Hf) solderers and 2 gas solderers during (shadowed area) and after cadmium exposure.

\section{Results}

\section{IN AIR}

The air concentration at $\mathrm{Hf}$ soldering with $\mathrm{Cd}$ solder seldom exceeded $90 \mathrm{nmol} / \mathrm{m}^{3}\left(10 \mu \mathrm{g} / \mathrm{m}^{3} ;\right.$ Table 4). The time-weighted average level was about 30 $\mathrm{nmol} / \mathrm{m}^{3}\left(3 \mu \mathrm{g} / \mathrm{m}^{3}\right)$. Most particles were smaller than $0 \cdot 1 \mu \mathrm{m}$, almost all smaller than $1 \mu \mathrm{m}$ (Table 5).

The irregular frequency of gas soldering in the industries made reliable estimations of time-weighted levels of $\mathrm{Cd}$ in air impossible.

CD IN BLOOD AND URINE DURING EXPOSURE Blood and urine samples were collected repeatedly during exposure. There was a considerable interindividual variation of $\mathrm{Cd}$ levels in blood (Fig. 1). In Hf solderers concentrations ranged from $<10$ $440 \mathrm{nmol} / \mathrm{l}(<1-49 \mu \mathrm{g} / \mathrm{l})$ on ten occasions over a six-month period. Considerable individual variation with time was also noted; the maximum range found was $150-440 \mathrm{nmol} / 1(17-49 \mu \mathrm{g} / \mathrm{l})$ in Hf solderer 3. In urine samples obtained on five occasions levels ranged from $<0.5$ to $27 \mu \mathrm{mol} \mathrm{Cd} / \mathrm{mol}$ creatinine $(=\mu \mathrm{g} / \mathrm{g}$ creatinine; Fig. 1$)$. In general the levels of $\mathrm{Cd}$ in urine varied less than those in blood, although in some subjects single values deviated from the individual overall concentration (for example, in $\mathrm{Hf}$ solderer 4). In the Hf solderers regression analysis revealed a statistically significant increase of $\mathrm{Cd}$ in urine when exposure time increased $(n=21$; $t=7.0$; P $<0.001$; Fig. 2). However, the variation was considerable. In the gas solderers levels in blood ranged from 45 to $150 \mathrm{nmol} / 1(5-17 \mu \mathrm{g} / \mathrm{l})$ and in urine from two to $20 \mu \mathrm{mol} / \mathrm{mol}$ creatinine $(=\mu \mathrm{g} / \mathrm{g}$ creatinine; Fig. 1).

Fig. 3 shows the relationship between Cd levels 


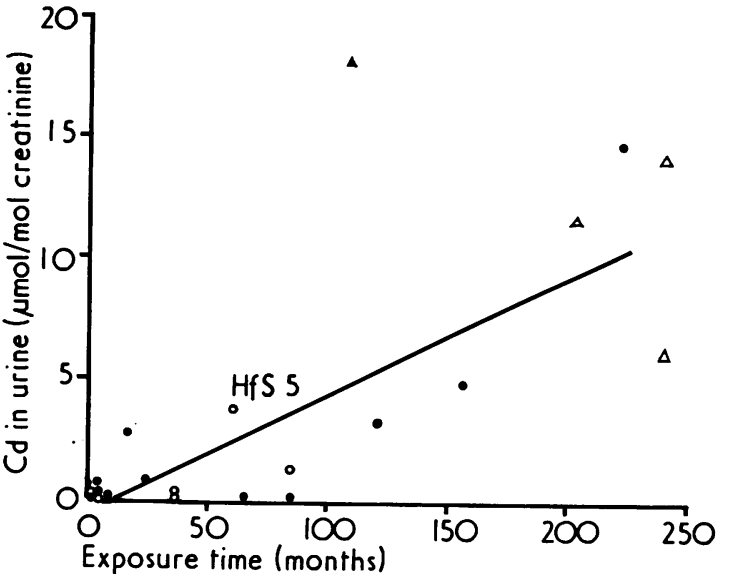

Fig. 2 Relationship between levels of cadmium in urine and exposure time in 21 high frequency solderers (Hf S; circles) and 4 gas solderers (triangles). Closed symbols denote smokers, open non-smokers. The regression line $(y=0.04 x-0.4)$ is calculated for $H f$ solderers only. Hf $S 5$ had not been occupationally exposed to $C d$ for 15 years before sampling.

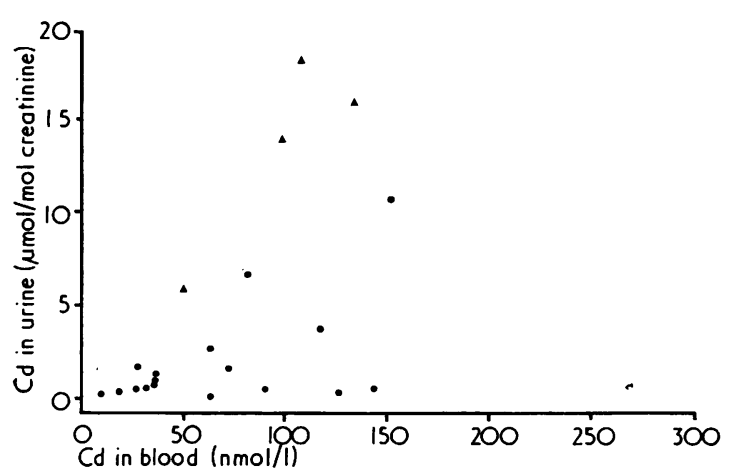

Fig. 3 Relationship between cadmium levels in blood and urine in 18 high frequency solderers (dots) and 4 gas solderers (triangles) during cadmium exposure.

in blood and urine in one day of sampling. There was no significant increase of $\mathrm{Cd}$ in urine with increasing levels of $\mathrm{Cd}$ in blood $(\mathrm{n}=22 ; t=1.3 ; \mathrm{P}>0.05)$.

\section{IN BLOOD AND URINE AFTER THE END}

OF EXPOSURE

In most workers there was a decay of blood $\mathrm{Cd}$ levels after the end of exposure (Fig. 1). Sufficient data to permit a closer analysis were present in 18 Hf solderers and all four gas solderers. Seven $\mathrm{Hf}$ solderers after a decay period reached a level of $<10 \mathrm{nmol} / 1$ ( $<1 \mu \mathrm{g} / \mathrm{l}$; for example Hf solderer 3$)$. Twelve workers (11 $\mathrm{Hf}$ solderers and one gas

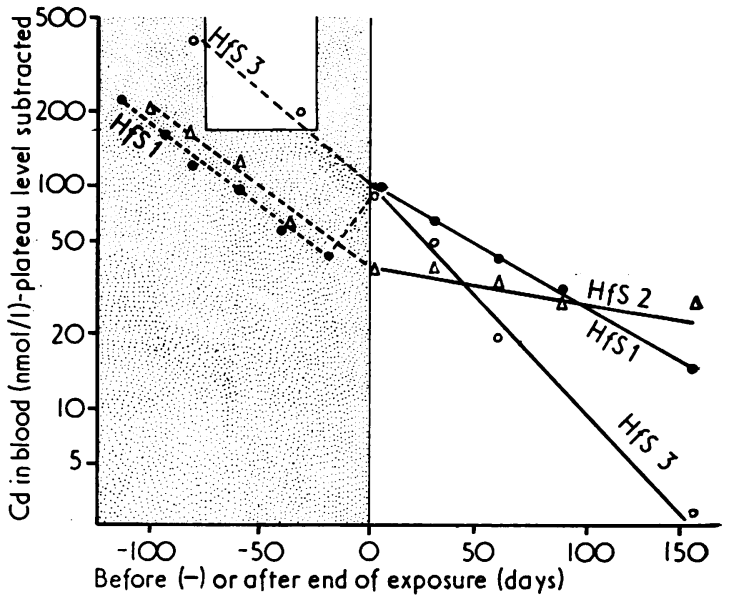

Fig. 4 Levels of cadmium in blood (logarithms, plateau levels subtracted) in 3 high frequency solderers (Hf S) during (shadowed area) and after cadmium exposure. In Hf $S 3$ exposure temporarily stopped (non-shadowed area) before finally ceasing (on day 0 ).

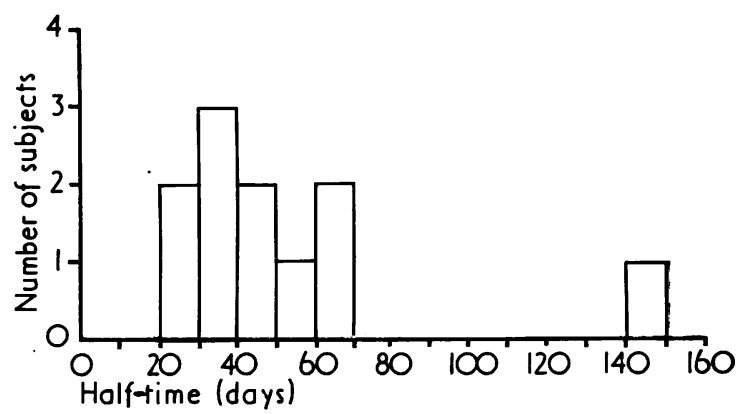

Fig. 5 Biological half-times of cadmium in blood in 11 high frequency solderers after the end of cadmium exposure.

solderer) reached a plateau level of $10 \mathrm{nmol} / 1$ $(1 \mu \mathrm{g} / \mathrm{l})$ or higher (for example, Hf solderers 1,2 , and 4 , and gas solderer 2). In three gas solderers there was little or no decay (for example, gas solderer 1). In $11 \mathrm{Hf}$ solderers in whom it was possible to analyse the decay kinetics more closely, the decay curves fitted single exponential functions (Fig. 4). The half-times (Fig. 5) in 10 workers ranged from 25 to 66 days (median 41 days), but in one worker ( $\mathrm{Hf}$ solderer 2) was 146 days.

Changes of $\mathrm{Cd}$ levels in urine after end of exposure were considerably less marked than in blood. It was not possible to estimate half-times. To get a rough picture, a rectilinear regression curve was. calculated in each subject on $\mathrm{Cd}$ in urine with regard to time after end of exposure. In 17 subjects (Hf solderers) with overall $\mathrm{Cd}$ levels in urine 
during and after exposure below $5 \mu \mathrm{mol} / \mathrm{mol}$ creatinine $(=\mu \mathrm{g} / \mathrm{g}$ creatinine $)$, the slopes ranged from a decrease of 0.03 to an increase of 0.08 (median was an increase of 0.03 ) $\mu \mathrm{mol} / \mathrm{mol}$ creatinine $\cdot 100$ days $^{-1}$. There was a tendency (not statistically proved) to decay when levels of $\mathrm{Cd}$ in urine were high. In six subjects (four gas solderers and two Hf solderers) with levels of 6-16 (median 13) $\mu \mathrm{mol} / \mathrm{mol}$ creatinine, the slopes ranged from an increase in one subject of 0.03 to a decrease of 2 (median was a decrease of 0.5$) \mu \mathrm{mol} / \mathrm{mol}$ creatinine $\cdot 100$ days $^{-1}$. However, it must be realised that these figures are uncertain to some degree.

Fifteen months after the end of exposure there was a statistically significant $(n=25 ; t=14.4$; $P<0.001)$ increase of $\mathrm{Cd}$ in urine with increasing levels of $\mathrm{Cd}$ in blood (Fig. 6).

\section{PROTEINS IN URINE}

In samples obtained 11-15 months after the end of exposure total protein excretion in urine ranged from 1.1-11 (mean 4.5) $\mathrm{g} / \mathrm{mol}$ creatinine (range $10-100$, mean $40 \mathrm{mg} / \mathrm{g}$ creatinine). There was no statistically significant increase in total protein excretion with increasing Cd levels in urine $(\mathrm{n}=25$; $t=1.7 ; \mathrm{P}>0.05$ ).

The relationship between $\beta_{2}$-microglobulin excretion in urine (range $1 \cdot 1-18$, mean $6 \cdot 7$, median $4.7 \mathrm{mg} / \mathrm{mol}$ creatinine; range $10-160$, mean 59 , median $42 \mu \mathrm{g} / \mathrm{g}$ creatinine) on the one hand and $\mathrm{Cd}$ levels in urine (Fig. 7) and age on the other was studied by multiple regression analysis. There was a statistically significant increase of $\beta_{2}$-microglobulin with increasing $\mathrm{Cd}$ levels in urine when possible

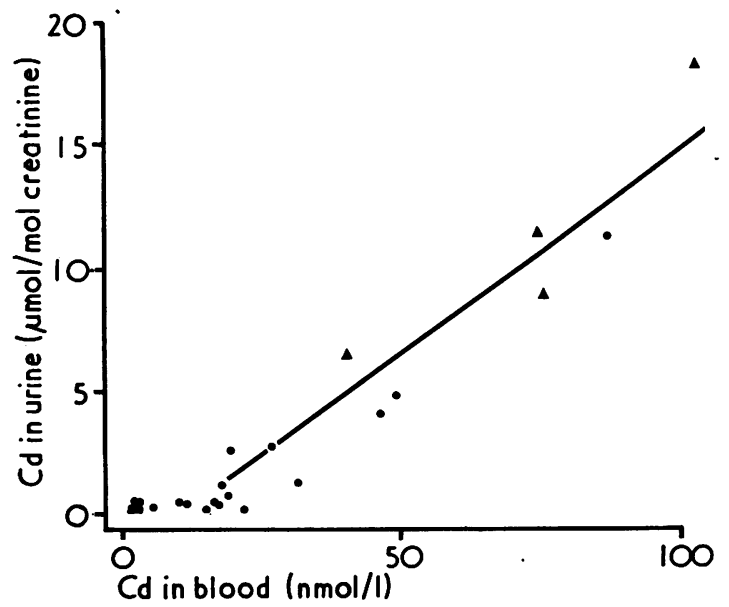

Fig. 6 Relationship between levels of cadmium in blood and urine in 21 high frequency solderers (dots) and 4 gas solderers (triangles) 15 months after the end of cadmium exposure. $y=0 \cdot 16 x-1 \cdot 6$.

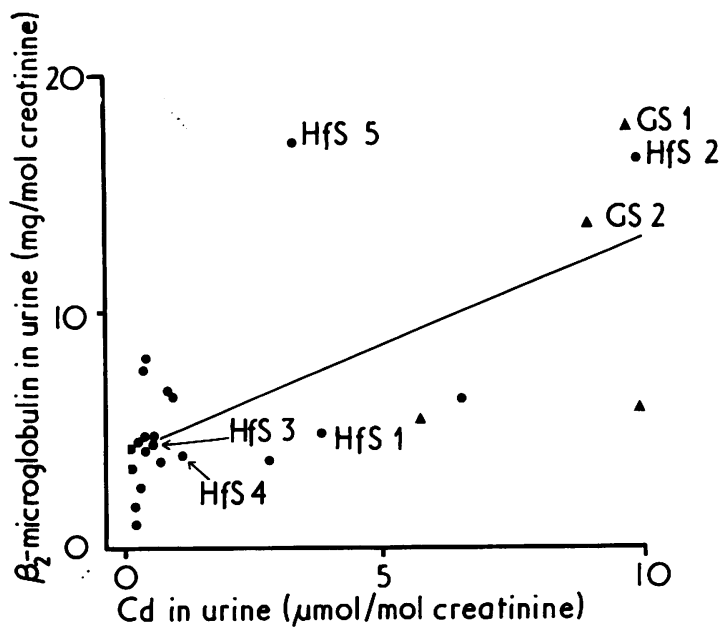

Fig. 7 Relationship between levels of cadmium and $\beta_{2}$-microglobulin in urine in 21 high frequency solderers (Hf S; dots) and 4 gas solderers (GS; triangles) 11-15 months (in Hf S 5, 16 years) after the end of exposure. $y=0.9 x-4 \cdot 2$.

influence of age had been eliminated $(\mathrm{n}=25$; $t=2.6 ; 0.01<\mathrm{P}<0.05$ ), while no corresponding effect of age could be established $(t=1 \cdot 1 ; \mathrm{P}>0.05)$. It should be noted that one subject (Hf solderer 5) had not been exposed to cadmium for 16 years before sampling. His levels of $\mathrm{Cd}$ in urine decreased at an approximate rate of $0.03 \mu \mathrm{mol} / \mathrm{mol}$ creatinine $\cdot 100$ days $^{-1}$.

\section{Discussion}

The smoke collected from $\mathrm{Hf}$ soldering with $\mathrm{Cd}$ solder and analysed for particle size showed a predominance of very small particles. Even if the content of $\mathrm{Cd}$ in particles of different size is not known, it is reasonable to assume that a large part of the $\mathrm{Cd}$ inhaled was retained in the lungs of the workers and was absorbed into their bodies. Most of the Cd levels in air recorded in this study were low when compared to the threshold limit values (TLV) for Cd fume in workroom air in different countries (USA $50 \mu \mathrm{g} / \mathrm{m}^{3}\left(440 \mathrm{nmol} / \mathrm{m}^{3}\right)$, (American Conference of Governmental Industrial Hygienists, 1976); Sweden $20 \mu \mathrm{g} / \mathrm{m}^{3}\left(180 \mathrm{nmol} / \mathrm{m}^{3}\right)$, (Swedish National Board of Occupational Safety and Health, 1974)).

As pointed out in the Materials and methods section, a minor fraction of the smallest particles may have escaped through the filters, but even taking that possibility into account, the exposures were low. The way in which Hf soldering was carried out seemed to be constant or at least fairly constant in each worker and also similar in different workers. 
In spite of this, it transpired that considerable variations occurred during the air sampling periods. Fairly extensive sampling was carried out on three occasions. It is possible that even larger variations may have occurred. The reason for the variations is not fully understood, although it is clear that the size of the pieces soldered and the number of soldering operations on each shaft are important factors. It is also reasonable to assume that the condition of the ventilation equipment at each bench as well as the individual working pattern may have affected the levels, although the conditions in this respect could not be adequately mapped.

A striking feature in several $\mathbf{H f}$ solderers was a decrease in blood $\mathrm{Cd}$ levels even before the end of exposure. The decrease started at about the time when the first results were shown to the workers, which might offer an explanation in terms of better working hygiene. However, one of the three air sampling periods occurred after the blood Cd levels had started to decrease and the air levels recorded then did not deviate compared to the earlier measurements. It is probable that a decrease of exposure occurred as a result of better hygiene with regard to eating and smoking at the work benches.

It is extremely difficult to estimate present and especially previous exposures. The working conditions in the typewriter factory had been improved by providing better work rooms and more efficient ventilation. This is of particular importance in the case of a cumulative agent like $\mathrm{Cd}$. It is almost impossible to assess other routes of exposure, such as food and cigarettes contaminated by dirty hands. It thus seems advisable to rely upon analysis of biological material for the assessment of risks of poisoning.

The Cd levels in blood and urine found in this study during exposure are in accordance with findings in other industries (Friberg et al., 1974; Kjellström, 1977). Most measurements exceeded the amounts reported in non-exposed subjects by different authors $(<10 \mathrm{nmol} / 1 \mathrm{in}$ blood and $<20 \mathrm{nmol} /$ day in urine).

There was an increase of Cd levels in urine with increasing duration of exposure. This might indicate a continuous accumulation but may also reflect a heavier exposure years ago.

The variations in blood $\mathrm{Cd}$ levels are striking: these may be due to variations in recent exposure, an assumption supported by the decrease in most subjects after exposure had ended. The levels in urine did not show the same pattern, and only a few workers had a significant but slow decrease after exposure. It is thus not surprising that there was no significant correlation between levels in blood and urine during exposure.
In many subjects it was possible to fit the decay of $\mathrm{Cd}$ in blood to a single exponential function. The half-time was fairly rapid and similar in different subjects but one worker deviated (Hf solderer 2). Scrutiny of his curve (Fig. 1) reveals that the levels started to decrease even before the end of exposure, probably due to reduction of exposure. If the full curve is considered, the levels decayed in a way consistent with the pattern found after the end of exposure in the other workers. It is thus probable that the long half-time obtained in that worker is due to minor analytical errors in some of the data making up the last part of the curve, but there is of course the possibility of an inter-individual variation in Cd metabolism, as has been reported in the case of methylmercury (Skerfving, 1974). Hf solderer 3, who had the highest blood $\mathrm{Cd}$, had biochemical indications of mild transient liver damage (see Materials and methods). His half-time did not deviate from that of the other workers. Although liver damage has been reported in some $\mathrm{Cd}$ workers (Friberg et al., 1974) it seems more probable that this worker suffered from hepatitis of other origin.

The half-times of 1-2 months found in this study are considerably shorter than those reported by Piscator (data quoted by Friberg et al., 1974) in a group of heavily exposed subjects. However, a close examination of the latter curves indicates that there is no obvious disagreement if the levelling off of blood $\mathrm{Cd}$ seen in some workers is taken into consideration. Recently, an average half-time of 80 days was computed from data obtained in newly-employed Cd workers (Kjellström, 1977).

The rapid decay of blood $\mathrm{Cd}$ might reflect redistribution of one or perhaps several pools of easily movable $\mathrm{Cd}$ in the body. It is well known that soon after exposure a large part of the $\mathrm{Cd}$ is present in the liver (Friberg et al., 1974). The rapid decay might mainly reflect that pool. In a few subjects nodefinite shift in blood Cd occurred, possibly because of low recent exposure, and after the first rapid decay the curves levelled off. In many subjects the level obtained was consistent with concentrations in non-exposed subjects. In others the plateau reached was considerably above normal levels. These levels may reflect one or several other pools, possibly present in the kidney which is known to contain a major part of the $\mathrm{Cd}$ in the body some time after exposure (Friberg et al., 1974). The low background exposure also contributes to a minor extent. As it is reasonable to assume that Cd levels in urine mainly reflect concentrations in the kidneys, one would expect a good correlation between levels in blood and urine after the end of exposure, which was also the case.

Certainly a single exponential function is too 
simple a model to describe the blood Cd curve. The level obtained after the initial decay is probably not the final one, as the elimination of $\mathrm{Cd}$ in urine in many workers considerably exceeded their assumed background exposure. It is known that the elimination of $\mathrm{Cd}$ from the body, mainly through the kidneys, is extremely slow; the half-time has been estimated at decades (Task Group on Metal Accumulation, 1973). It is thus not surprising that no decrease in blood $\mathrm{Cd}$ could be demonstrated during the limited observation period in the present workers after the first rapid decay, and that a decrease of $\mathrm{Cd}$ in urine was present only in a few workers and then only at a slow rate. This is in agreement with observations (Piscator, data quoted by Friberg et al., 1974) of a correlation between Cd levels in blood on the one hand and kidney damage (tubular proteinuria) on the other as much as 20 years after the end of heavy exposure.

Both total protein and $\beta_{2}$-microglobulin excretion in the present workers were within normal limits (Evrin and Wibell, 1972; Pharmacia Diagnostics AB, 1975). There was however a statistically significant increase in $\beta_{2}$-microglobulin excretion with rising $\mathrm{Cd}$ levels in urine, which was not explained by age. Increased elimination of $\beta_{2}$-microglobulin in urine is an early sign of renal tubular damage, which is in turn the first toxic effect of Cd exposure (Subcommittee on the Toxicology of Metals, 1976). Although only a small sample of workers was studied, and there is a possibility that the workers showing the highest urinary $\mathrm{Cd}$ levels might have had even higher $\mathrm{Cd}$ concentrations in urine at an earlier stage as a result of poorer working conditions, the present results may indicate a slight effect on tubular function from $\mathrm{Cd}$ exposure at levels in urine even of the order of $10 \mu \mathrm{mol} / \mathrm{mol}$ creatinine. Data on $\beta_{2}$-microglobulin reported by Piscator (in Friberg et al., 1974) and Kjellström (1977) also indicate effects at low urinary $\mathrm{Cd}$ concentrations. Higher $\mathrm{Cd}$ levels have been found by several authors in workers with proteinuria (Friberg et al., 1974; Lauwerys et al., 1974; Tsuchiya, 1975). However, the methods used were less sensitive as indices of tubular dysfunction than the radioimmunological $\beta_{2}$-microglobulin analyses employed in the present study.

This study was supported by grant 73/134 from the Swedish Work Environment Fund. We wish to express our thanks to the workers and management of the factories studied. Statistical advice was given by Jan Rise, PhD, and Bengt Rignér, PhD. Valuable developmental work on $\mathrm{Cd}$ analyses was undertaken by Andrejs Schütz, BSc, and technical assistance by Mrs Lisbeth Frank.

\section{References}

American Conference of Governmental Industrial Hygienists (ACGIH) (1976). Threshold Limit Values (TLVs) for Chemical Substances and Physical Agents in the Workroom Environment with Intended Changes. ACGIH: Cincinatti, Ohio, USA.

Evrin, P-E., and Wibell, L. (1972). The serum levels and urinary excretion of $\beta_{2}$-microglobulin in apparently healthy subjects. Scandinavian Journal of Clinical and Laboratory Investigation, 29, 69-74.

Friberg, L., Piscator, M., Nordberg, G. F., and Kjellström, T. (1974). Cadmium in the Environment, 2nd edition. CRC Press: Cleveland, Ohio, USA.

Kjellström, T. (1977). Accumulation and renal effects of cadmium in man. A dose-response study. Department of Environmental Hygiene: Karolinska Institute, Stockholm.

Lauwerys, R. R., Buchet, J.-P., Roels, H. A., Brouwers, J., and Stanescu, D. (1974). Epidemiological survey of workers exposed to cadmium. Archives of Environmental Health, 28, 145-148.

Perkin-Elmer Corporation (1968). Analytical methods for atomic absorption spectrometry. The Perkin-Elmer Corporation: Norwalk, Connecticut, USA.

Pharmacia Diagnostics AB (1975). Phadebas $\beta_{2}$-micro Test. Clinical and Technical Information. Pharmacia: Uppsala, Sweden.

Piscator, M. (1962). Proteinuria in chronic cadmium poisoning. II. The applicability of quantative and qualitative methods of protein determination for the demonstration of cadmium proteinuria. Archives of Environmental Health, 5, 325-332.

Skerfving, S. (1974). Methylmercury exposure, mercury levels in blood and hair, and health status in Swedes consuming contaminated fish. Toxicology, 2, 3-23.

Subcommittee on the Toxicology of Metals (1976). Effects and Dose-Response Relationships of Toxic Metals. Edited by G. F. Nordberg. Elsevier: Amsterdam.

Swedish National Board of Occupational Safety and Health (1974). Maximum Allowable Concentrations. Liber förlag: Vällingby, Sweden. (In Swedish.)

Task Group on Metal Accumulation (1973). Accumulation of toxic metals with special reference to their absorption, excretion, and biological half-times. Environmental and Physiological Biochemistry, 3, 65-107.

Teger-Nilsson, A. C. (1961). Serum creatinine determinations using an ion exchange resin. Scandinavian Journal of Clinical and Laboratory Investigation, 13, 323-331.

Tsuchiya, K. (1975). Proteinuria of cadmium workers. In Abstracts of XVIII International Congress on Occupational Health, Brighton, England, 14-16 September, 1975, pp. 286-287. Congress Organising Committee: Brighton. 